\title{
Synthesis and Antibacterial Activity of 1,3-Diallyltrisulfane Derivatives
}

\author{
Fang-Kui Ren, Xiao-Yan He, Li Deng, Bo-Heng Li, Dong-Soo Shin, ${ }^{\ddagger}, *$ and Zhu-Bo Li* \\ College of Phamaceutical Sciences, Southwest Cniversity. Chongaing foo716, China \\ ${ }^{\dagger}$ High School Attached to Southwest Normal Lniversitw, Chongqing t00715, China \\ -Department of Chemistry. Changwon National University. Changw'on. GN 6+1-733, Korea \\ E-mail: dsshiniáchangwon ac $\mathrm{w}^{\prime}$ \\ Received October 29, 2008, Accepted February 5, 2009
}

\begin{abstract}
A series of novel 1,3-diallyltrisulfane analogues were synthesized and assayed in vito for antimicrobial activity against Gram positive, Gran negative bacteria and fungi. The antimicrobial activity of the 1,3-diallyltrisulfane derivatives showed, on the whole, very potent towards all the tested Gram positive, Gram negative and fungi (MIC ranging from 4 to $256 \mu \mathrm{gg} / \mathrm{mL}$ ). 1,3-Di(pent-4-enyl)trisulfane 3b and 1,3-bis(3-methylbut-2-eny:l)trisulfane 3e exhibited the strongest antibacterial activity among all the compounds, and both of them were more active than 1,3-diallyltrisulfane (DATS). Results indicated the relationship of either carbon number or lipophilicity with antimicrobial activity presented " $\mathrm{V}$ " shape. These observations provided some predictions in order to further design 1,3-diallyltrisulfane derivatives with antimicrobial activity.
\end{abstract}

Key Words: Diallylsulfane. Diallyldisulfane, Diallyltrisulfane, Antimicrobial activity. Biological activity

\section{Introduction}

Garlic (Alithm satimim L.) has long been recognized to be nature plant medical. ${ }^{3}$ Garlic contains abundance of organosulfur compounds. such as dially'sulfane (DAS), 1.2-diallyldisulfane (DADS) and 1,3-dially ltrisulfane (DATS) (Scheme 1). On the other hand. thio ether and double bond has been indicated as an important pharmacophore and privileged structure in medicinal chemistry..$^{\hat{-1}}$ producing a diverse range of biological activities including antibacterical " antiparasite. antiviral. anticancer. ${ }^{8}$ antitumor, antioxidation ${ }^{1(1-11}$ and anticardiovascular activities. ${ }^{12}$ Usually 1.3-diallyltrisulfane was synthesized by unsaturated alkyl halide, sodium thiosulfate and sodium sulfide in DMSO. THF or $\mathrm{H}_{2} \mathrm{O}-\mathrm{EtOH}$. Buffer solutions or expensive metal catalysts were used in some reactions. ${ }^{13.16}$ Until now 1.3-diallyltrisulfane derivatives were not reported. Herein. we improved the method and synthesized novel 1.3 -diallyltrisulfane derivatives $3 \mathbf{a}-3 \mathbf{e}$, containing longer chain and branched allyl moieties in the structures. All the compounds were tested for in vitro antimicrobial properties against Gram positive. Gram negative bacteria and fungi, and exhibited excellent activity. The structure-activity relationship of the 1.3-diallyltrisulfane derivatives was studied.

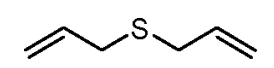

dially|sulfane (DAS)

$$
\text { 1,3-diallyltrisulfane (DATS) }
$$

\section{Materials and Methods}

All chemicals and solvents used were of AR grade and DATS was purchased from Institute of Biology: the Chinese Academy of Sciences. Extracted solvents were dried over anlydrous $\mathrm{Na}_{2} \mathrm{SO}_{4}$. followed by evaporation under vacuum. ${ }^{1} \mathrm{H}$ NMR and ${ }^{13} \mathrm{C}$ NMR spectra were recorded in $\mathrm{CDCl}_{3}(400$ $\mathrm{MHz}$ for ${ }^{1} \mathrm{H} \mathrm{NMR}$ and $100 \mathrm{MHz}$ for ${ }^{13} \mathrm{C} N \mathrm{NR}$, respectively) with TMS as the internal reference on Bnuker Advance $400 \mathrm{FT}$ spectroneter. Chemicals shifts were reported in parts per million. Mass spectra (MS) were measured by EPCI method. IR spectra were recorded, as $\mathrm{KBr}$ pellets. on a Jasco FT-IR $300 \mathrm{E}$ spectrophotometer (Jasco Ltd.. Japan) and the reported wave numbers were given in $\mathrm{cm}^{-1}$. Silica gel (200-300 mesh) was used for flash colunin chromatography. All the reactions were monitored by TLC using $0.25 \mathrm{~mm}$ silica gel plates (Merck 60F-254) with UV indicator. The ClogP values were calculated using ChemDraw Ultra 8.0.

General procedure for the synthesis. To the saturated aqueous solution of sodiun thiosulfate $(0.13 \mathrm{~mol})$. was added the unsaturated alkyl bromide $(0.1 \mathrm{~mol})$ dropwise at $50-60^{\circ} \mathrm{C}$. kept stirring. When the solution turned clear. the reaction mixture was cooled to room temperature and standing for separation. To the under layer the sodium sulfide solution ( 30 $\mathrm{mL}, 0.001 \mathrm{~mol} / \mathrm{mL}$ ) was added. kept stirring at room temperature overnight. The upper layer of the reaction mixture was washed by water and dried over aqueous sodium sulfate. Cnude products were purified by column chromatography. yielding $80-90 \%$ of the products.

1,3-Di(but-3-enyl)trisulfane(3a): light-yellow oil: IR (KBr) $v_{\max } 3078,2978,2922,2844,1835,1639.1435,1415,1273$. $1215,992,914.749 .634,478 \mathrm{~cm}^{-1}$; ${ }^{1} \mathrm{H}$ NMR $(400 \mathrm{MHz}$, $\left.\mathrm{CDCl}_{3}\right) \tilde{\delta} 2.49-2.55(\mathrm{~m}, 4 \mathrm{H}), 2.94(\mathrm{t}, J=7.6 \mathrm{~Hz}, 4 \mathrm{H})$, 5.05-5.1+(m, +H). 5.79-5.89 (m, 2H): ${ }^{13} \mathrm{C} \mathrm{NMR}(100 \mathrm{MHz}$, $\left.\mathrm{CDCl}_{3}\right)$ 833.0, 37.9. 116.5. 134.0: $\mathrm{MS}(\mathrm{APCI}) \mathrm{n} / \mathrm{z} 206\left[\mathrm{M}^{-}\right]$.

Scheme 1. Diallylsulfanes in garlic 
1,3-Di(pent-t-enyl)trisulfane (3b): light-yellow oil: IR (KBr) $v_{\text {max }} 3074,2974,2929,2848,1828,1640,1434,1414,1272$. 1208. 989. 913. 748, 638, $478 \mathrm{~cm}^{-1}$; $\mathrm{H}$ NMR $(400 \mathrm{MHz}$. $\left.\mathrm{CDCl}_{3}\right) \delta 1.82-1.90(\mathrm{~m},+\mathrm{H}) .2 \cdot 16-2.21(\mathrm{~m},+\mathrm{H}) .2 .88(\mathrm{t}, J=$ $7.2 \mathrm{~Hz}, 4 \mathrm{H}), 4.99-5.08(\mathrm{~m} .+\mathrm{H}) .5 .75-5.85(\mathrm{~m} .2 \mathrm{H}){ }^{13} \mathrm{C} \mathrm{NMR}$ (100 $\left.\mathrm{MHz} . \mathrm{CDCl}_{3}\right) \delta 23.0 .32 .4$. 38.1. 115.4. 137.5: MS (APCI) $\mathrm{m} / \mathrm{z} 235\left[\mathrm{M}^{+}\right]$

3-Di(hex-5-enyl)trisulfane (3c): light-yellow oil: IR (KBr) $v_{\max } 3074,297+, 2928,2855,1827,1639,1435,1+15,1273$. 1215.992.916.741,634, $478 \mathrm{~cm}^{-1}:{ }^{1} \mathrm{H}$ NMR (400 MHz. $\left.\mathrm{CDCl}_{3}\right)$ ò $1.48-1.56(\mathrm{~m}, 4 \mathrm{H}) .1 .73-1.80(\mathrm{~m} .4 \mathrm{H}), 2.06-2.12(\mathrm{~m}$, $+\mathrm{H}) .4 .65(\mathrm{t} . J=7.2 \mathrm{~Hz}, 4 \mathrm{H}) .4 .94-5.05(\mathrm{~m},+\mathrm{H}) .5 .75-5.86(\mathrm{~m}$. $2 \mathrm{H}) ;{ }^{13} \mathrm{C}$ NMR $\left(100 \mathrm{MHz} . \mathrm{CDCl}_{3}\right) \delta 27.7 .28 .2,38.7 .114 .8$. 138.4: MS (APCI) $\mathrm{m} / \mathrm{z} 262\left[\mathrm{M}^{+}\right]$.

1,3-Bis(2-methylallyl)trisulfane (3d): light-yellow oil; IR (KBr) v $v_{\text {max }} 3079.2972 .2938,2914,2854,1801.1648 .1449$. 1374. $1219,1010,897,742,641,479 \mathrm{~cm}^{-1}:{ }^{1} \mathrm{H}$ NMR $(400$ $\left.\mathrm{MHz} \mathrm{CDCl}_{3}\right) \delta 1.84$ (s. $\left.6 \mathrm{H}\right), 3.46(\mathrm{~s}, 4 \mathrm{H}), 4.94$ (d. $J=6.4 \mathrm{~Hz}$, $+\mathrm{H}){ }^{3 \hat{3} \mathrm{C} \mathrm{NMR}}\left(100 \mathrm{MHz}, \mathrm{CDCl}_{3}\right)$ ò 20.9.46.4. 115.6. 140.0: $\mathrm{MS}$ (APCI) $\mathrm{m} / \mathrm{z} 206\left[\mathrm{M}^{+}\right]$.

1,3-Bis(3-methylbut-2-enyl)trisulfane (3e): light-yellow oil: IR (KBr) $v_{\max } 3025,2969,2935,2857,1665,1634,1448$. $1376,1207.1104 .981,888,767,693,478 \mathrm{~cm}^{-1}:{ }^{1} \mathrm{H}$ NMR (400 $\left.\mathrm{MHz}, \mathrm{CDCl}_{3}\right) \ddot{o} \mathrm{l} .72(\mathrm{~s}, 6 \mathrm{H}), 1.76(\mathrm{~s} .6 \mathrm{H}), 3.56(\mathrm{~d} . J=8.0 \mathrm{~Hz}$. $4 \mathrm{H}) .5 .30(\mathrm{t}, J=8.0 \mathrm{~Hz} .2 \mathrm{H}):{ }^{13} \mathrm{C} \mathrm{NMR}\left(100 \mathrm{MHz} . \mathrm{CDCl}_{3}\right)$ oे 18.0. 25.8. 36.8. 118.5. 138.2: MS (APCI) $\mathrm{m} / \mathrm{z} 235\left[\mathrm{M}^{+}\right]$

Micnobiology. The in vitro antimicrobial activity was assayed by the two fold broth dilution teclunique against Gram positive bacteria (Staphylococcus atrets ATCC 25923. Bacillts subtilis ATCC 6633 and Micrococcus luteus ATCC 4698). Gram negative bacteria (Escherichia coli ATCC 25922. Proteus vulgaris ATCC 6896 and Pseudomonas aeruginosa ATCC 27853) and fungi (Candida albicans ATCC 76615. Saccharomyces cerevisiae ATCC 9763 and Aspergillas niger ATCC 16404). The minimal inhibitory concentration (MIC, $\mu \mathrm{g} / \mathrm{mL}$ ) was defined as the lowest concentration of compound that completely inluibited the growth of each strain. ${ }^{17}$ DATS was used as reference antibacterial and antifungal substance. Test compounds were dissolved in $\mathrm{H}_{2} \mathrm{O}$ containing $1 \%$ DMSO and diluted into different concentrations from 1 to 512 $\mu \mathrm{g} / \mathrm{mL}$ with liquid medium. The concentration of mixture of 1,3-diallyltrisulfane derivatives and inocula was $5.00 \times 10^{5}$ bacteria $/ \mathrm{mL}$ and $1.00 \times 10^{4}$ fungi/mL. It was incubated at 37 " $\mathrm{C}$ for $24 \mathrm{~h}$ for bacteria in broth mediunt. and at $25^{\circ} \mathrm{C}$ for $48 \mathrm{~h}$ for the fungus in improved Sabouraud medium. Microbial growth was examined by measuring the absorbance at $655 \mathrm{~mm}$ with spectrophotometer. The $\mathrm{H}_{2} \mathrm{O} / 1 \%$ DMSO was used as a blank. inoculation bacterial not medicine as positive control. All experiments were run in triplicate.

\section{Results \& Discussion}

Chemistry. Unsaturated alkyl bromide 1 (1.0 equiv) was slowly added to saturated solution of sodium thiosulfate at $50-60^{\circ} \mathrm{C}$. The second step involved addition of sodium sulfide (1.0 equiv) to the product of salt 2 in solution obtained in the first step, to afford 1.3-dially ltrisulfane derivatives 3 . y ielding $80-90 \%$. In all the reactions. only water was used as solvent instead of any other organic solvents, which led to "green chemistry" compared with other methods (Scheme 2). As shown in Table 1 , the reaction tine and carbon number of compound 1 had significant effect on the yield of the products. As the carbon number of unsaturated alkyl bromide increased. the reaction time increased accordingly ( $\mathbf{3 a}$ to $\mathbf{3 c}$ ). Longer reaction time resulted in lower yield of product $3(89.2 \%$ to $82.0 \%$ ). The experintental data of $\mathbf{3 d}$ and $\mathbf{3 e}$ were also in accordance with such conclusion. The structures of 1.3 -diallyltrisulfane derivatives, 3a-3e were confirmed by IR. ${ }^{1} \mathrm{H}$ NMR, ${ }^{12} \mathrm{C}$ NMR and MS spectral data.

Antimicnobial activity. The 1,3-diallyltrisulfane deriva tives. 3a-3e were assayed in vitro for their antinucrobial activity against the Gram positive. Gram negative bacteria and fungi (Table 2), in comparison with 1,3-diallyltrisulfane and the minimal inhibitory concentrations that inhibited the growth of the tested microorganisms (MIC) were detected.

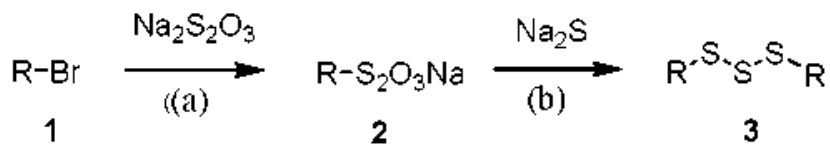

Scheme 2. Design of the target compounds 3a-3e. Reagents and condition: (a): $\mathrm{H}_{2} \mathrm{O}, 50-600^{\circ} \mathrm{C}$ ( (b): $\mathrm{H}_{2} \mathrm{O}$, r.t., $80-90 \%$

Table 1. Synthesis 1,3-diallyltrisulfane derivatives

Entry

${ }^{a}$ All products were characterized by IR. MS, ${ }^{1} \mathrm{H}$ and ${ }^{13} \mathrm{C}$ NMR spectra. ${ }^{5}$ The reaction time of the first step. ${ }^{\circ}$ Isolated yields after column purification. 
All the compounds displayed good inhibition of the growth of Gram positive and Gram positive bacteria. including Staphylococcus aurets. Bacilhis stibtifis. Hicrococcus huteus. Escherichia coli. Proteus vulgaris and Pseudomonas aeruginosa and Fungi. Candida albicans. Saccharomuces cerevisiae. Aspergillus niger. Most compounds exhibited MIC values in the range of 4-256 $\mu \mathrm{g} / \mathrm{mL}$, and the MC values were represented (Table 2). Some of novel 1,3-diallyltrisulfane derivatives exhibited activity stronger than DATS. The data obtained indicated that the antibacterial activity against Gram positive bacteria was weaker than Gram negative bacteria, and fungi activity was the lowest (Figure 1). It is noteworthy that. among the 1,3-diallyltrisulfane derivatives the inhibitory effect appeared to be dependent on chain length and carbon number.

As shown in Table 2, all the compounds except $3 \mathrm{c}$ were more active than DATS. Compounds $3 \mathbf{b}$ and $\mathbf{3 c}$ containing ten carbon atoms showed stronger antibacterial activity than $\mathbf{3 a}$ and $3 \mathrm{e}$ with eight carbons. and $3 \mathrm{a}$ and $3 \mathrm{e}$ exhibited stronger activity than DATS which contains only six carbon atoms. Whereas, the antimicrobial activity of $3 \mathrm{c}$, which contains twelve carbons. became lower than DATS and other derivatives (3a $\mathbf{3 b}, \mathbf{3 d}$ and $\mathbf{3 e}$ ). In summary the relationship of carbon number of product 3 with the antibacterial activity presented " $\mathrm{V}$ " shape (Figure 2). In addition. branched 1.3diallyltrisulfane analogues (3d and 3e) showed higher antimicrobial activity than straight chained 1.3-diallỵltrisulfane analogues (3a and $3 \mathbf{b}$ ). MIC value of straight chained compounds from DATS to $3 \mathbf{a}$ and $\mathbf{3 b}$ decreased. with increase of corresponding $C \log P$ value (Table 2), which indicated the increase of antibacterial activity. Whereas, the MIC value of compound $\mathbf{3 c}$ was higher than DATS. 3a and $\mathbf{3 b}$. also with ligher ClogP than DATS, 3a and 3b. The lipophilicity of branched compounds from $3 \mathrm{~d}(\mathrm{C} \log \mathrm{P}=4.52)$ to $3 \mathrm{e}(\mathrm{C} \log \mathrm{P}=$ 5.58 ) showed an increase tendency in accordance with the increase of antibacterial activity. ${ }^{18}$ This meant the relationship of lipophilicity and antibacterial activity also presented "V" shape

Among all the tested compounds. 3b and 3e exhibited the

Table 2. Antimicrobial activity of $3 \mathrm{a}-3 \mathrm{e}$ expressed as MIC ( $\lfloor\mathrm{g} / \mathrm{mL})$

\begin{tabular}{|c|c|c|c|c|c|c|c|c|c|c|}
\hline \multirow{3}{*}{ Entry } & \multirow{3}{*}{ CLog $P^{4 i}$} & \multicolumn{6}{|c|}{ Microorganismsns } & \multirow{2}{*}{\multicolumn{3}{|c|}{ Fungid }} \\
\hline & & \multicolumn{3}{|c|}{ Gram-positive ${ }^{b}$} & \multicolumn{3}{|c|}{ Gram-negative $^{c}$} & & & \\
\hline & & $\mathrm{SA}$ & BS & MI & $\mathrm{EC}$ & PV & PA & $\mathrm{CA}$ & $\mathrm{SC}$ & AN \\
\hline DATS & 3.72 & 64 & 32 & 64 & 32 & 64 & 64 & 64 & 64 & 64 \\
\hline $3 a$ & 4.38 & 16 & 32 & 32 & 32 & 32 & 32 & 32 & 256 & 64 \\
\hline $3 b$ & 5.44 & 8 & 32 & 16 & 32 & 64 & 8 & 16 & 128 & 16 \\
\hline $3 c$ & 6.50 & 32 & 32 & 64 & 64 & 256 & 32 & 256 & 256 & 128 \\
\hline $3 d$ & 4.52 & 32 & 32 & 64 & 32 & 32 & 32 & 64 & 128 & 64 \\
\hline $3 \mathrm{e}$ & 5.58 & 16 & 32 & 8 & 32 & 32 & 4 & 8 & 128 & 8 \\
\hline
\end{tabular}

${ }^{a}$ Lipophilicity reported as calculated $\log$ of partition coefticient $(\mathrm{Clog} P$ values). "Gram positive bacteria: SA, Staphlococous antens (ATCC 25923): BS, Bacilhis subtilis (ATCC 6633): MI. Hicrococcts hutetis (ATCC 4698). 'Gram negative bacteria: EC. Escherichia coli (ATCC 25922); PV. Protens ralgatis (ATCC 6896); PA, Psewdomonas aemgimosa (ATCC 27853). "Yeasts (Fungi): CA. Candida albicms (ATCC 76615); SC. Sacharomices cerevisiae (ATCC 9763); AN. Aspergillas niger (ATCC 164()4).

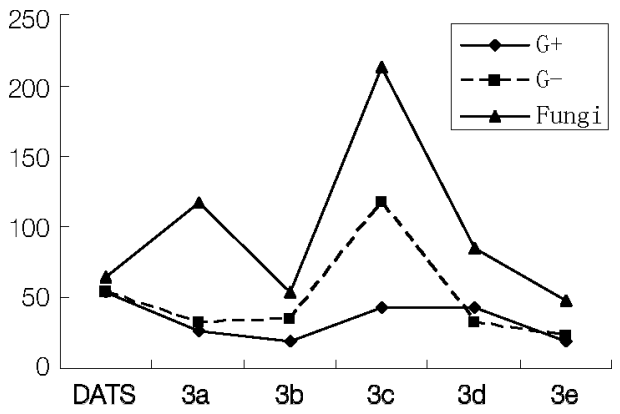

Fig 1. The average activity ( $h \mathrm{~g} / \mathrm{mL}$ ) against $\mathrm{G}+$, $\mathrm{G}$ - and fungi of 1,3 -diallyltrisulfane derivatives (3a-3e).

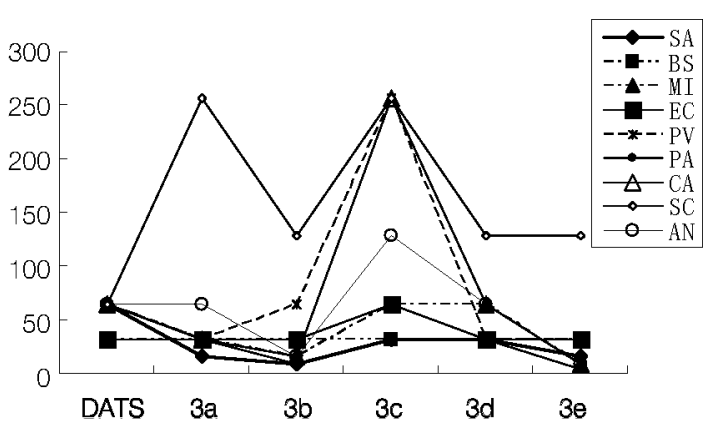

Fig 2. Antibacterial activity $(\mu \mathrm{g} / \mathrm{mL})$ of 1,3 -diallyltrisulfane derivatives $(3 \mathrm{a}-3 \mathrm{e})$.

best antibacterial activity against Gram positive. Gram negative bacteria and Fungi. The MIC value of $\mathbf{3 b}$ against Gram positive. Staphlococcus cureus was $8 \mu \mathrm{g} / \mathrm{mL}$. and compound $3 \mathrm{e}$ showed the highest activity against hicrococcus luteus ( 8 $\mu \mathrm{g} / \mathrm{mL}$ ). As regarding for the activity against the Gram negative bacteria, 3b exhibited $8 \mu \mathrm{g} / \mathrm{mL}$ of MIC value against Pseudomonas aeruginosa. and the MIC of $3 \mathrm{e}$ was $4 \mu \mathrm{g} / \mathrm{mL}$ against Pseudomonas aeruginosa. The lowest MIC value against fungi was obtained by compound $3 \mathrm{e}$. which gave MIC value of $8 \mu \mathrm{g} / \mathrm{mL}$ against Candida albicans and Aspergillus niger (Figure 2). Branched 3e showed stronger antibacterial activity than straight chained 3b (Figure 2). Among all the tested compounds. $3 \mathrm{c}$ showed the lowest antibacterial activity. All the synthesized novel compounds showed lower activity than DATS against Saccharomyces cerevisiae. These observations provided some predictions in order to design further antimicrobial active compounds prior to their synthesis following with molecular modeling studies.

\section{Conclusion}

Novel 1.3-diallyltrisulfane analogues 3a-3e were synthesized by improved method and assayed in vitro for the evaluation of their antimicrobial activity against Gram positive, Gram negative bacteria and fungi. The antimicrobial activity of the 1,3-diallyltrisulfane derivatives showed. on the whole. very potent towards a wide spectnum of Gram positive. Gram negative and fungi (MIC ranging from + to $256 \mu \mathrm{g} / \mathrm{mL}$ ). Compounds $3 \mathrm{~b}$ and $3 \mathrm{e}$ exhibited the best antibacterial activity among all the new conpounds. Data 
obtained suggested that chain length and carbon number played an important role on the antimicrobial properties of this class of compounds. The good properties of the novel class of antibacterial substances deserve further investigation in order to clarify the mode of action at molecular level. responsible for deeper insight into structure-activity relationship and to optimize the effectiveness of the 1.3-diallyltrisulfane derivatives.

Acknowledgments. This study was supported by the Key Project of the Municipal Natural Science Foundation of Chongqing. China (grant No. CSTC. 2008 A A 1001).

\section{References}

1. Corzo-Martinez, M.; Corzo, N.; Villamiel, M. Trends Food Sci. Tech. 2007, 18, 609-625.

2. Moriguchi, T.: Matsuura, H.; Kodera, Y.; Itakura, Y; Katsulki, H.: Saito, H.; Nishivama, N. Veurochentical Research 1997, 22, $1449-1452$

3. Augusti, K. T.; Sheela, C. G. Cell Mol Life Sci. 1966, 52, $115-$ 119

4. Oi, Y, Kawada, T: Shishido, C.; Wada, K: Kominato, Y.; Nishinura, S.: Ariga, T.: Iwa, K. J. Nutrition 1999, 129, $336-342$.
5. Curtis, H.; Noll, U.; Stömann, J.; Slusarenko, A. J. Plysiol. Hol. Plant Pathol 2004, 65, 79-89.

6. Saleheen, D.: Ali, S. A.: Yasinzai, M. M. Fitoterapia 2004, 75 , 9-13.

7. Weber, N. D.; Anderson, D. O.; North, J. A.; Murray; B. K:; Lawson, L. D.; Hughes, B. G. Planta hed. 1999, 58, $417-123$.

8. Oommen, S.; Anto, R. J.; Srinivas, G.; Karunagaran, D. Eur. $J$. Pharmacol 2004, $485,97-103$.

9. Whl, C. C.; Chung, I. G.; Tsai, S. T.; Yang, J. H.; Sheen, L. Y. Food Chem. Toxicol 2004, 12, 1937-1947.

10. Wu, C. C.; Sheen, L. Y.; Chen, H. W; Tsai, S. J.; Lii, C. K. Food Chem Toxicol 2001, 39, 563-569.

11. Yin, M. C.; Cheng, W. S. Heat Sci. 2003, 63, 23-28.

12. Gargner, C. D.; Chatterjee, L. M.: Carlson, I. J. Atherosclerosis $2001,15+, 213-220$

13. Zhu, Y:Zhao, M. Z; Xu, M. X. Chinese J. Syn. Chent 2001, 9, $541-542$.

14. Sinha, P.; Kundu, A.: Roy, S. Organometallics 2001, 20, $157-162$

15. Block, E.: Lyer, R.: Grisoni, S.: Saha, C.: Belman, S.; Lossing, F. P. J. im Chem. Soc. 1988, 110, $7813-7827$.

16. Block, E.; Almad, S.; Catalfamo, J. L.; Jair, M. K.; Apitz-Castro, R. J. Am. Chem. Soc. 1986, 108, 7045-7055.

17. Ma, X. R. Beijing: People Health Publishing House 2001, $50-53$.

18. Phillips, O. A.: Udo, E. E.; Samuel, S. M. Eur. J. Med Chem. 2008, $43,1095-1104$. 